\title{
LA CRISIS DE LOS CONTROLADORES AÉREOS Y LA COVID-19 COMO EMERGENCIAS CONSTITUCIONALES INSUFICIENTEMENTE REGLADAS. PROPUESTAS DE LEGE FERENDA PARA EL ESTADO DE ALARMA ${ }^{1}$
}

\author{
Pablo Fernández de Casadevante Mayordomo \\ Profesor Contratado Doctor Interino, \\ Universidad Rey Juan Carlos
}

Cómo citar este artículo / Citation: Fernández de Casadevante Mayordomo. (2021). La crisis de los controladores aéreos y la covid-19 como emergencias constitucionales insuficientemente regladas. Propuestas de lege ferenda para el estado de alarma. Garrido López, C. (coord.) Excepcionalidad y Derecho: el estado de alarma en España, Colección Obras colectivas, Fundación Manuel Giménez Abad, Zaragoza. DOI: https://doi.org/10.47919/FMGA.OC21.0010

SUMARIO: I. INTRODUCCIÓN. II. EL DERECHO DE EMERGENCIA CONSTITUCIONAL COMO PUNTO DE PARTIDA: 1. Las emergencias constituciones regladas. 2. Las emergencias constitucionales no regladas. III. SOBRE LA INSUFICIENCIA REGULATORIA EN LOS ESTADOS DE ALARMA DECLARADOS EN ESPAÑA: 1. Normativa general básica de los estados excepcionales. 2. Marco jurídico específico aplicable al estado de alarma. 3. La crisis de los controladores aéreos como emergencia constitucional... ¿insuficientemente reglada? 4. El elemento no reglado en la crisis sanitaria por covid-19. IV. PROPUESTAS DE LEGE FERENDA

\footnotetext{
${ }^{1}$ Este artículo se encuentra vinculado al proyecto de investigación con referencia DER201676312-P
} 


\section{INTRODUCCIÓN}

El fenómeno de la emergencia constitucional sitúa al Estado democrático constitucional ante una difícil tesitura en el momento de su configuración. En concreto, deberá decidir si los mecanismos habituales, previstos para situaciones de normalidad, serán suficientes para conjurar las amenazas extraordinarias que puedan surgir a lo largo del tiempo. Y, claro, en caso de respuesta negativa, se verá en la situación de tener que lograr articular la manera en que la asunción de poderes extraordinarios por parte del Gobierno sea compatible con el establecimiento de unos contrapesos suficientes para evitar caer en conductas autoritarias².

Consciente de ello, y respetando dichas premisas, el constituyente español consagró un artículo 116 CE cuya misión fundamental es la preservación del orden constitucional de manera que, una vez superada la crisis surgida, pueda procederse al restablecimiento inmediato de la normalidad políticoconstitucional $^{3}$. Nos referimos a los estados de alarma, excepción y sitio, institutos cuya regulación concreta se encuentra condicionada por lo dispuesto en el artículo 55.1 CE.

Pues bien, antes de entrar en el estudio de su aplicación práctica -hasta la fecha, solo se ha recurrido al estado de alarma-, y a los efectos de una explicación lo más didáctica posible, realizaremos una breve aproximación al fenómeno de las emergencias constitucionales regladas y no regladas, figuras incluidas dentro de lo que nosotros entendemos que es el derecho de emergencia constitucional. Acto seguido comprobaremos, ya sí, hasta qué punto los estados de alarma declarados en España contienen elementos propios de ambas categorías para, por último, completar el trabajo con la realización de alguna reflexión en materia de lege ferenda.

\footnotetext{
${ }^{2}$ LOEWENSTEIN, K., Teoría de la Constitución, Ariel, Barcelona, $2^{\underline{a}}$ edición (4aㅡ reimpresión), 1986, p. 286.

${ }^{3}$ DE ESTEBAN, J. y GONZÁLEZ-TREVIJANO, P., Tratado de Derecho Constitucional. Tomo II, $2^{\mathrm{a}}$ edición, Universidad Complutense de Madrid, Madrid, 2004, p. 479.
} 


\section{EL DERECHO DE EMERGENCIA CONSTITUCIONAL COMO PUNTO DE PARTIDA}

Como bien señala nuestra doctrina clásica, es "evidente que los Estados no siempre viven en plena normalidad, con funcionamiento regular y perfecto de los organismos, instituciones y servicios en que su actuación se desenvuelve. Surgen a veces en la comunidad política perturbaciones de variada importancia que pueden (...) llegar incluso a conmociones que afectan en grado máximo a la existencia misma del Estado"4. Pues bien, en el momento en el que esa habitualidad se rompe, deberá estar justificado que las reglas ordinarias cedan en gran medida, ello si lo que se quiere es la pronta restauración de la normalidad político-constitucional.

El actual contexto de terrorismo global, las crisis migratorias que ponen en jaque la capacidad del Estado para controlar sus fronteras y garantizar la continuidad del sistema, los extremismos políticos que persiguen la destrucción del orden democrático o, como ahora, las catástrofes naturales y crisis sanitarias de gran magnitud que obligan a la restricción extraordinaria de derechos fundamentales. Estos son solo algunos ejemplos de situaciones de anormalidad constitucional que, a pesar del carácter excepcional que les es propio, suelen ser anticipadas por los poderes constituyentes, ello a los efectos de proporcionar la mayor seguridad y garantías jurídicas posibles. Y decimos que esa es la actitud habitual porque también hay sistemas jurídicos que pasan por alto dicha cuestión, fiando la superación de la crisis al derecho de necesidad ${ }^{5}$. De hecho, lo lógico es que el recurso a este último agilice la respuesta estatal ante el peligro concreto, ello si lo comparamos con los formalismos propios de aquellos sistemas que se hayan decantado por constitucionalizar la anormalidad constitucional. Ahora bien, siendo cierto lo anterior, no lo es menos que el aumento en ese dinamismo será directamente proporcional a la inseguridad jurídica generada ante el supuesto excepcional no regulado, problema frente al que la regulación exhaustiva parece ser el modelo que mejor parado sale ${ }^{6}$. Además, lo bueno de ese último método es

\footnotetext{
${ }^{4}$ PÉREZ SERRANO, N., Tratado de Derecho Político, 2a edición, Civitas, Madrid, 1984, p. 418.

${ }^{5}$ O Notrecht, en alemán, según terminología empleada por LOEWENSTEIN, K., Teoría de la Constitución, op. cit., p. 286 -la obra original vio la luz en inglés y con otro título, en 1957-. O fuerza mayor, en palabras de WIGNY, P., Droit Constitucionnel, Bruxelles, Établissements Émile Bruylant, 1952, pp. 198-200.

${ }^{6} \mathrm{~A}$ favor de regular las situaciones excepcionales, entre otros, FERNÁNDEZ SEGADO, F., EI estado de excepción en el derecho constitucional español, Madrid, Edersa, 1978, p. 19; y tORRES DEL MORAL, A., Principios de Derecho Constitucional Español. Tomo I, Madrid,
} 
que, partiendo de la imposibilidad de anticipar todos los peligros susceptibles de producirse a lo largo de la vida de un Estado, ante el hecho excepcional no regulado en su totalidad siempre cabrá la apreciación del estado de necesidad. $Y$, es que, lo contrario nos llevaría al absurdo de tener que aceptar la claudicación del Estado de derecho cuando las previsiones normativas extraordinarias se revelasen insuficientes para asegurar su defensa frente a unos peligros que, como decimos, pueden adoptar las formas más variopintas. Ahora bien, la combinación entre recurso a los estados excepcionales y el derecho de necesidad no puede darse de cualquier manera. En caso de producirse un vacío normativo en la aplicación de los primeros, el salto a la necesidad ha de tener lugar desde el instrumento jurídico más ajustado -por su casuística, las medidas aplicables y sus correspondientes garantías- a la crisis sobrevenida.

Por lo tanto, y recapitulando. Si todo Estado de derecho, en cuanto que "Estado sujeto a normas", se basa en la aplicación habitual y general de una serie de reglas jurídicas preestablecidas, las situaciones de anormalidad constitucional suponen la aplicación de un régimen jurídico sustancialmente distinto. $Y$ ante dicha tesitura, los sistemas constitucionales han reaccionado de manera diferente. Mientras unos optan por ignorar el fenómeno, otros deciden incluir ciertas previsiones al respecto, ya sea de manera más o menos detallada, sin que ello garantice tampoco la plena regulación de las crisis susceptibles de producirse a lo largo del tiempo.

Es así como diferenciamos entre las emergencias constitucionales regladas y las no regladas, categorías ambas de lo que en otro trabajo hemos venido a denominar derecho de emergencia constitucional ${ }^{8}$. Un instituto que entra en juego cuando la amenaza al orden constitucional es de tal gravedad que hace necesaria la afectación de cualquiera de los cuatro pilares básicos de todo

Universidad Complutense de Madrid, 5a edición, 2004, p. 576. En contra, en cambio, LAFUENTE BALLE, J. M., "Los estados de alarma, excepción y sitio (I)", en Revista de Derecho Político, núm. 30, 1999, p. 30, para quien "la tesis que mejor responde frente a un supuesto de crisis constitucional es la (...) teoría de la fuerza mayor", dada "la desvirtualidad del Derecho de excepción".

${ }^{7}$ DE ESTEBAN, J., y GONZÁLEZ-TREVIJANO, P., Tratado de Derecho Constitucional. Tomo II, op. cit., p. 469, para quienes la naturaleza del Estado de derecho "se basa (...) en tres presupuestos delimitadores: normatividad, generalidad y normalidad".

${ }^{8}$ Vid. "El derecho de emergencia constitucional en España: hacia una nueva taxonomía", en Revista de Derecho Político, no 107 (2020), pp. 111-145. 
Estado de derecho9: el imperio de la ley -incluida la Ley Constitucional-, en caso de que la amenaza surgida no estuviera contemplada en ella; la eficacia de los derechos fundamentales, si hubiera que imponer medidas suspensivas en la materia; el principio de división de poderes, cuando se alteren las reglas habituales de distribución de los mismos; y el sometimiento de la Administración al principio de legalidad, si aquella tuviera que adoptar medidas no previstas expresamente en la Constitución ni en las leyes.

Sentadas las premisas básicas de lo que es el derecho de emergencia constitucional, es hora ya de proceder al estudio de las dos variantes básicas que, como decíamos, puede adoptar dicho instituto dependiendo del tipo de cobertura jurídica de la que disfruten las medidas impuestas en defensa del Estado: las emergencias constitucionales regladas y las no regladas. $Y$, en este sentido, ya se ha indicado también la posibilidad de que, ante una amenaza determinada, puedan concurrir elementos propios de una u otra disciplina.

\section{Las emergencias constituciones regladas}

En este sentido, hablaremos de emergencia constitucional reglada cuando la respuesta estatal ante la amenaza se encuentre previamente contemplada en la Constitución o en las leyes, de manera que se pueda deducir suficientemente: 1) cuáles son las situaciones de emergencia constitucional susceptibles de producirse; 2) a quién corresponde su apreciación, declaración o aplicación; 3) qué medidas pueden adoptarse en cada caso; 4) y cuáles son los mecanismos de control y/o garantías existentes ante el recurso a esa potestad extraordinaria.

Ahora bien, con el fin de evitar una rigidez excesiva a la hora de determinar si se cumplen o no las condiciones enumeradas, debe admitirse que algunas de las mismas puedan ser recogidas por medio de conceptos jurídicos indeterminados, lo cual no debe llevar a la automática catalogación de la

\footnotetext{
${ }^{9}$ Aunque con sus respectivos matices, esos cuatro elementos básicos son enumerados por ÁLVAREZ CONDE, E., El Régimen Político Español, 4ª edición, Tecnos, Madrid, 1990, pp. 34 a 37; ALZAGA VILLAAMIL, O., GUTIÉRREZ GUITIÉRREZ, I., y RODRÍGUEZ ZAPATA, J., Derecho Político Español según la Constitución de 1978 (I). Constitución y fuentes del Derecho, 4aㅡ edición, Editorial Universitaria Ramón Areces, Madrid, 2007, p. 275; y SÁNCHEZ FERRIZ, R., El Estado Constitucional. Configuración histórica y jurídica. Organización funcional, Tirant lo Blanch, Valencia, 2009, pp. 112 y 113.
} 
emergencia constitucional como no reglada ${ }^{10}$. Eso sí, la regulación positiva ha de ser suficiente para poner fin a la situación de crisis surgida.

\section{Las emergencias constituciones no regladas}

En contraposición con la anterior categoría, serán emergencias constitucionales no regladas o insuficientemente regladas aquellas amenazas que no se encuentren convenientemente previstas en la Constitución o en las leyes. Además, será solo en estos casos cuando, a nuestro modo de ver, tenga sentido hablar de un supuesto jurídico de excepción, visión contraria a la defendida por la doctrina, que acostumbra a condicionar la apreciación del estado de excepción -entendido en sentido amplio- o derecho de excepción a la existencia de regulación previa aplicable ${ }^{11}$, artículo 116 CE a la cabeza.

Para nosotros, en cambio, la auténtica excepción jurídico-política se produce en relación con aquellos supuestos que, por su carácter extraordinario, logran escapar al afán regulatorio del poder constituyente y del legislador. Son situaciones más propias del estado de necesidad antes descrito, lo cual no significa que la autoridad estatal disponga de plena libertad para adoptar cualesquiera medidas.

En efecto, el aseguramiento del rápido y completo restablecimiento de la normalidad constitucional estará sujeto necesariamente a una serie de reglas jurídicas, discrepando así de Carl Schmitt cuando afirma que, ante el supuesto no previsto en el ordenamiento jurídico, desaparece toda referencia jurídica que guíe la actuación defensiva del Estado ${ }^{12}$. Para nosotros, el faro que debe

\footnotetext{
${ }^{10}$ Para nosotros, la no regulación se asocia principalmente con el estado de necesidad, mientras que la dictadura comisarial o constitucional, tal y como está regulada en el artículo 16 de la Constitución francesa, bien puede catalogarse como emergencia constitucional mínima o suficientemente reglada.

${ }_{11}$ En este sentido, por ejemplo, FERNÁNDEZ SEGADO, F., El estado de excepción en el Derecho constitucional español, op. cit.; CRUZ VILLALÓN, P., Estados excepcionales y suspensión de garantías, Tecnos, Madrid, 1984; o el propio Tribunal Constitucional en su STC 83/2016, de 28 de abril, FFJJ 7 y 10. Para una exposición completa de los argumentos que nos llevan a apartarnos de esa posición tan ampliamente extendida, FERNÁNDEZ DE CASADEVANTE MAYORDOMO, P., "El derecho de emergencia constitucional en España: hacia una nueva taxonomía", en Revista de Derecho Político, no 107 (2020), pp. 119 y ss. A partir de ahí, cuando en este trabajo hablamos de estados excepcionales para referirnos genéricamente a los del artículo $116 \mathrm{CE}$, lo hacemos simplemente para no introducir excesivo ruido en el sistema.

${ }^{12}$ SCHMITT, C., Politische Theologie: vier Kapitel zur Lehre von der Souveranität, Duncker und Humblot, München, 2004, pp. 18 y ss, al señalar que la apreciación del estado de excepción exige "la suspensión total del orden jurídico vigente", añadiendo poco después que, "ante un
} 
alumbrar el camino hacia la normalidad constitucional es el respeto a ciertos principios y valores democráticos básicos, en cuanto que pilares fundamentales del modelo democrático configurado por el poder constituyente de 1978. De hecho, y en contra de lo sostenido por la academia especializada ${ }^{13}$, es justamente en estas situaciones no reguladas -es decir, las que para nosotros dan lugar a la apreciación de lo que realmente es un estado jurídico excepcional- donde el verdadero derecho constitucional de excepción hará acto de presencia. Ello, claro, siempre y cuando se observen esos elementos jurídicos básicos pues, de lo contrario, estaremos ante una auténtica actuación contra constitutionem.

¿Y cuáles son esos criterios a los que nos referimos? De manera muy resumida, podría decirse que son los valores superiores del ordenamiento jurídico -artículo 1.1 CE-, los principios generales del derecho -artículo 9.3 CEy la aplicación del principio de proporcionalidad, cuya superación exige, en palabras del Tribunal Constitucional, la previa verificación de tres condiciones: "(i) adecuación de la medida al objetivo propuesto (juicio de idoneidad); (ii) necesidad de la medida para alcanzar su objetivo, sin que sea posible su logro a través de otra más moderada con igual eficacia (juicio de necesidad) y (iii) ponderación de la medida por derivarse de ella más beneficios o ventajas para el interés general que perjuicios sobre otros bienes o valores en conflicto (juicio de proporcionalidad en sentido estricto)"14.

\section{III.SOBRE LA INSUFICIENCIA REGULATORIA EN LOS ESTADOS DE ALARMA DECLARADOS EN ESPAÑA}

\section{Normativa general básica de los estados excepcionales}

Una vez descritos los fundamentos teóricos básicos del derecho de emergencia constitucional, es hora de centrarse ya en la figura del estado de alarma, el

caso excepcional, el Estado suspende el derecho en virtud del derecho a su propia conservación".

${ }_{13}$ De nuevo, con FERNÁNDEZ SEGADO, F., El estado de excepción en el derecho constitucional español, op. cit., p. 19 -aunque él emplea el término "estado de excepción"-; y CRUZ VILLALÓN, P., Estados excepcionales y suspensión de garantías, op. cit., pp. 31 y ss., al frente.

${ }^{14}$ STC 64/2019, de 9 de mayo, FJ 5. En la misma línea, por ejemplo, las SSTC 66/1995, de 8 de mayo, FJ 5; 55/1996, de 28 de marzo, FFJJ 6, 7, 8 y 9; 207/1996, de 16 de diciembre, FJ 4 e); 37/1998, de 17 de febrero, FJ 8; y 39/2016, de 3 de marzo, FJ 5. 
único de los mecanismos contemplados en el artículo 116 CE que ha sido aplicado hasta la fecha ${ }^{15}$.

Pues bien, dicho instituto se encuentra consagrado en el artículo 116.2 CE, en virtud del cual "el estado de alarma será declarado por el Gobierno mediante decreto acordado en Consejo de Ministros por un plazo máximo de quince días, dando cuenta al Congreso de los Diputados, reunido inmediatamente al efecto y sin cuya autorización no podrá ser prorrogado dicho plazo. El decreto determinará el ámbito territorial a que se extienden los efectos de la declaración".

Desarrollado por Ley Orgánica 4/1981, de 1 de junio, de los estados de alarma, excepción y sitio -LOEAES, en adelante-, y antes de entrar en la regulación específica del mismo, el estado de alarma se encuentra igualmente condicionado por una serie de criterios generales que, afectando de una manera u otra a los tres mecanismos del artículo $116 \mathrm{CE}$, resultan de especial interés de cara a analizar con espíritu crítico la aplicación concreta del mismo en nuestro país ${ }^{16}$.

A saber: 1) el mandato de continuidad en el normal funcionamiento de los poderes constitucionales del Estado durante lo que dure cualquiera de los estados excepcionales -artículos 116.5 CE y 1.4 LOEAES $^{17}$-; 2) la no modificación del principio de responsabilidad del Gobierno y de sus agentes durante ese tiempo -artículos 116.6 CE y 3 LOEAES-; 3) la atribución exclusiva al estado de sitio de la capacidad de sometimiento del personal civil a la jurisdicción militar -artículos 117.5 CE y 35 LOEAES-; 4) la igual circunscripción

\footnotetext{
${ }^{15}$ Llegados a este punto, conviene precisar algo que ya apuntamos en La defensa de la Constitución. El derecho de emergencia constitucional y el artículo 55 CE, Thomson ReutersAranzadi, 2020, pp. 139 y ss., y es que el estado de alarma no encaja realmente dentro del concepto de derecho de emergencia constitucional, pues entendemos no concurren ninguna de las condiciones exigidas para ello. A pesar de todo, hemos decidido comenzar el estudio con el apartado teórico visto, no solo a los efectos de una mejor sistemática, sino por la relevancia que adquiere el estado de excepción del artículo 116.3 CE -integrante ya sí de ese derecho de emergencia constitucional- dentro del análisis de las emergencias enfrentadas en los años 2010 y 2020.

${ }^{16}$ De esta forma, dejamos fuera cuestiones por otra parte no menores, como la prohibición expresa de iniciar la reforma constitucional, tanto en vigencia de los estados excepcionales, como en tiempos de guerra -artículo 116.5 CE-. Sobre las críticas doctrinales a esta previsión, vid. VERA SANTOS, J. M., "La reforma del procedimiento de reforma constitucional en España", en Revista de Derecho Político, núm. 96, mayo-agosto 2016, pp. 13-48.

17 En el caso de las Cortes Generales, el artículo 78.2 CE atribuye a las Diputaciones Permanentes correspondientes la asunción de las funciones propias de las Cámaras para los estados de alarma, excepción y sitio, ello para el caso de que estas se encontrasen disueltas o hubiera expirado su mandato.
} 
a los estados de excepción y de sitio, de la posibilidad de adoptar medidas en materia de suspensión de determinados derechos fundamentales -artículo 55.1 CE-; 5) la obligación de recurrir a los estados excepcionales solo cuando los poderes ordinarios del Estado fueran insuficientes para atajar el peligro extraordinario, debiéndose optar por las medidas estrictamente indispensables, que además habrán de ser aplicadas de manera proporcionada a las circunstancias surgidas -artículos 1.1 y 1.2 LOEAES-

Como decíamos, se tratan estas de unas reglas que, en mayor o menor medida, serán traídas a colación a la hora de valorar la adecuación o no a derecho de los estados de alarma declarados en España desde 1978.

\section{Marco jurídico específico aplicable al estado de alarma}

Constituyendo el artículo 116 CE una especie de "norma cuadro"18 para que el legislador especifique posteriormente el grueso de la regulación aplicable a cada uno de los estados excepcionales ${ }^{19}$, veamos cuál es el resultado de esa delegación normativa, fijándonos nosotros solo en los aspectos del estado de alarma más relevantes para el objeto de este trabajo.

\section{A) Presupuestos de hecho}

Así, y respecto a los presupuestos de hecho que permiten proceder a su declaración, el artículo 4 LOEAES alude a los siguientes:

a) Catástrofes, calamidades o desgracias públicas como, por ejemplo, terremotos, inundaciones, incendios urbanos y forestales o accidentes de gran magnitud.

b) Crisis sanitarias, tales como epidemias y situaciones graves de contaminación.

c) Paralización de servicios públicos esenciales para la comunidad, cuando no se pudiera garantizar el mantenimiento de unos servicios mínimos básicos, como establecen los artículos 28.2 y 37.2 CE.

\footnotetext{
${ }^{18}$ FERNÁNDEZ-FONTECHA TORRES, M., "Artículo 116”, en CAZORLA PRIETO, L. M. (Dir.) y Palomar Olmeda, A. (Coord.) Comentarios a la Constitución Española de 1978. Tomo II, Aranzadi, Navarra, 2018, p. 429.

${ }_{19}$ Así lo establece expresamente el artículo $116.1 \mathrm{CE}$, al señalar que "Una ley orgánica regulará los estados de alarma, de excepción y de sitio, y las competencias y limitaciones correspondientes".
} 
Además, deberá concurrir alguna de las demás circunstancias 0 situaciones previstas en este artículo 4 LOEAES.

d) Situaciones de desabastecimiento de bienes de primera necesidad.

Visto lo cual, la principal duda respecto a este precepto estriba en su imprecisión a la hora de determinar cuál es la naturaleza del presupuesto de hecho habilitante ${ }^{20}$. En concreto, cabe plantearse si el estado de alarma se encuentra previsto únicamente frente a emergencias provocadas por fenómenos naturales y grandes accidentes o su declaración es posible, de igual modo, en situaciones de conflicto colectivo.

Pues bien, dado que el apartado c) del artículo 4 LOEAES exige la concurrencia de alguna de las demás situaciones contempladas en el precepto, resulta razonable descartar el estado de alarma para aquellos casos en los que la alteración de la normalidad tuviera como único origen la paralización de los servicios públicos esenciales para la comunidad en el marco de un conflicto laboral colectivo. De hecho, de la propia dicción del precepto se colige que la mera concurrencia de cualquiera de las circunstancias previstas en los apartados a), b) o d), son de por sí suficientes para justificar el recurso a esta institución, lo que despoja a la letra c) de toda utilidad o sentido ${ }^{21}$. Eso sí, aún podría interpretarse, forzadamente a nuestro entender, que las situaciones de desabastecimiento de productos básicos a las que se refiere el artículo $4 \mathrm{~d}$ ) LOEAES pudieran estar causadas por un conflicto social, pues nada se dice acerca de cuál ha de ser la causa que produzca esa falta de bienes de primera necesidad $^{22}$.

En definitiva, para nosotros resulta más razonable entender que el supuesto del apartado c) deba tener relación con el desastre natural, tecnológico o sanitario ya que, para las graves alteraciones provocadas por cuestiones

${ }^{20}$ DE ESTEBAN J., y GONZÁLEZ-TREVIJANO, P., Tratado de Derecho Constitucional. Tomo II, op. cit. 482.

${ }^{21}$ CRUZ VILLALÓN, P., Estados excepcionales y suspensión de garantías, op. cit., pp. 70; y ABA CATOIRA, A., "Estado de alarma en España", en Teoría y Realidad Constitucional, núm. 28,2011, p. 332.

${ }_{22}$ Igualmente, reacio a esa aproximación, LAFUENTE BALLE, J. M., "Los estados de alarma, excepción y sitio (II)", en Revista de Derecho Político, núm. 31, 1990, p. 31, para quien "el estado que la Ley Orgánica contempla para el desabastecimiento originado por la conflictividad social (art. 23) es precisamente el de excepción y no el de alarma". Por su parte, CRUZ VILLALÓN, Estados excepcionales y suspensión de garantías, op. cit., p. 71, contempla la posibilidad de que ese desabastecimiento pueda tener su origen en situaciones de crisis internacionales. 
políticas, conflictos socio-laborales incluidos, ya está, sobre todo, el estado de excepción -artículo 116.3 $\mathrm{CE}_{-}{ }^{23}$. Es por eso que estamos con quien afirma la "naturaleza no política de la emergencia" ${ }^{24}$ que justifica la declaración del estado de alarma, sin que ello obste para: 1) reconocer que la deficiente redacción del precepto da pie a otras tantas interpretaciones ${ }^{25}$, entre ellas la defendida por el Gobierno de cara a declarar el estado de alarma en 2010, asunto al que dedicaremos el apartado III.3. 2) Alertar, desde ahora, de que esa desvinculación inicial entre estado de alarma y orden público ${ }^{26}$ no impide que una catástrofe o calamidad inicialmente vinculable al estado de alarma pueda, a posteriori, devenir en otro fenómeno distinto, encuadrable ya sí dentro del concepto de orden público propio del estado de excepción -en cuanto al estado de sitio, su casuística requeriría una transformación de la situación todavía mayor- ${ }^{27}$. Sobre esto volveremos en el apartado III.4, al analizar lo sucedido en la lucha contra la covid-19.

\section{B) Declaración y control de las medidas}

Refiriéndonos ahora a la declaración y al control de las competencias ejercidas durante el estado de alarma, los artículos 116.2 CE y 4 LOEAES atribuyen al Gobierno la potestad para su declaración vía decreto acordado en Consejo de Ministros, en el cual deberá especificarse el ámbito territorial sobre el que se

${ }^{23}$ En esa misma línea, ÁLVAREZ CONDE, E., El Régimen Político Español, op. cit., p. 254; LAFUENTE BALLE, J. M., "Los estados de alarma, excepción y sitio (II)", op. cit., p. 31; PÉREZ ROYO, J., Curso de Derecho Constitucional, Marcial Pons, Madrid, 15a edición, 2016, pp. 847 y 848; y TORRES DEL MORAL, A., Principios de Derecho Constitucional Español, op. cit., p. 577. Reacio, en cambio, a excluir totalmente el elemento político de la ecuación, FERNÁNDEZ SEGADO, F., "Artículo 55", en ALZAGA VILLAAMIL, Ó. (Dir.), Comentarios a la Constitución Española de 1978, Tomo IV, EDERSA, Madrid, 1998, p. 614. Igualmente en contra, GOIG MARTÍNEZ, J. M., "La defensa política de la Constitución. Constitución y estados excepcionales. (II) Un estudio de Derecho constitucional comparado", op. cit., p. 225, para quien el estado de alarma "no excluye, sin embargo, su declaración ante situaciones sociales que perturben el normal desenvolvimiento de la vida política de la nación".

${ }_{24}^{24}$ PEREZ ROYO, J., Curso de Derecho Constitucional, op. cit., p. 847.

${ }^{25}$ Como señala CRUZ VILLALÓN, P., Estados excepcionales y suspensión de garantías, op. cit., p. 78, "el legislador ha seguido pensando en el estado de alarma como instrumento frente a situaciones excepcionales de conflictividad social", especialmente en relación con el artículo 11 c) y e) LOEAES.

${ }^{26}$ Nexo que, estando presente en el proyecto de Ley Orgánica de Seguridad Ciudadana de 1979, fue eliminado durante la tramitación de la LOEAES.

${ }^{27}$ Lo anterior es perfectamente compatible con la posición doctrinal mayoritaria, consistente en considerar que los estados de alarma, de excepción y de sitio, tal y como los configura la LOEAES, se refieren a tres supuestos diferenciados entre sí, previstos para otras tres situaciones de distinta naturaleza -se diferencian, por lo tanto, en atención a criterios cualitativos y no de intensidad-. Vid. FERNÁNDEZ SEGADO, F., "La Ley orgánica de los estados de alarma, excepción y sitio", Revista de Derecho Político, núm. 11. Otoño 1981, p. 95. 
proyectan los efectos de esa declaración. En este sentido, cuando los supuestos extraordinarios anteriormente descritos afecten a todo o parte del territorio de una Comunidad Autónoma, podrá ser su Presidente el que solicite al Ejecutivo la declaración de dicho estado de alarma -artículo 5 LOEAES- ${ }^{28}$. Por cierto, en virtud de jurisprudencia constitucional, el decreto de declaración -también el de prórroga- del estado de alarma se encuentra revestido de rango o valor de ley, por lo que su fiscalización solo podrá tener lugar por medio del control de constitucionalidad de las leyes, disposiciones y actos con fuerza o valor de ley, tal y como establecen los artículos 161 y 163 CE, y 27.2 b) LOTC $^{29}$.

En cuanto a la duración inicial del estado de alarma, será de quince días, debiendo el Gobierno dar cuenta al Congreso de los Diputados, reunido de inmediato al efecto, y sin cuya autorización no será posible prorrogar aquel plazo por un tiempo que la Constitución no concreta. Pues bien, esa indeterminación, que hasta hace poco no generaba mayores desvelos, constituye una importante grieta por la que, Gobierno y Congreso de los Diputados, han introducido en el año 2020 una prórroga que da la espalda a una de las reglas esenciales del derecho de emergencia constitucional, si no la principal: la existencia de un adecuado control parlamentario como contrapeso a los poderes ampliados del Gobierno en situaciones excepcionales. Sobre ello hablaremos en el apartado III.4.

Centrándonos ahora en la figura de la autoridad competente a los efectos del estado de alarma, la encarnará el Gobierno o el Presidente autonómico, por delegación del primero y solo para los casos en los que la declaración del estado de alarma se refiera únicamente a todo o parte del territorio de esa Comunidad Autónoma -artículo 7 LOEAES-. Esta premisa resulta fundamental

\footnotetext{
${ }^{28}$ Así sucedió con las peticiones formales extendidas al Gobierno central desde la mayoría de comunidades autónomas, en el sentido de que procediera a la declaración del tercer estado de alarma del año 2020, finalmente decretado en virtud de Real Decreto 926/2020, de 25 de octubre.

${ }^{29}$ STC 83/2016, de 28 de abril, FJ 11, no entrando el Alto Tribunal sobre el fondo del asunto. En cualquier caso, para mayor precisión y según dicha sentencia, revisten valor o rango de ley: 1) Los actos del Congreso de los Diputados consistentes en: a) la autorización para que el Gobierno pueda proceder, no solo a la prórroga del estado de alarma sino a la declaración y prórroga del estado de excepción; b) la declaración y prórroga del estado de sitio por la propia Cámara Baja, a propuesta del Ejecutivo. 2) Los decretos gubernamentales de declaración y prórroga de los estados de alarma y de excepción. Más al respecto en GARRIDO LÓPEZ, C., "Naturaleza jurídica y control jurisdiccional de las decisiones constitucionales de excepción", en Revista Española de Derecho Constitucional, núm. 110, mayo-agosto (2017), pp. 43-73.
} 
a la hora de criticar la delegación en los ejecutivos autonómicos realizada vía Real Decreto 926/2020, de 25 de octubre ${ }^{30}$.

\section{C) Medidas aplicables}

Fijándonos ahora en la panoplia de medidas susceptibles de ser aplicadas en vigencia del estado de alarma, el artículo 11 LOEAES contempla las siguientes:

a) Limitación de la circulación o de la permanencia de personas 0 vehículos en horas y lugares determinados, o su condicionamiento al cumplimiento de ciertos requisitos.

b) Práctica de requisas temporales de todo tipo de bienes e imposición de prestaciones personales obligatorias.

c) Intervención y ocupación transitoria de industrias, fábricas, talleres, explotaciones o locales de cualquier naturaleza, con excepción de domicilios privados, informando de ello a los Ministerios interesados.

d) Limitación o racionamiento del uso de servicios o del consumo de artículos de primera necesidad.

e) Impartición de las órdenes necesarias para asegurar el abastecimiento de los mercados y el funcionamiento de los servicios y de los centros de producción afectados como consecuencia de ese racionamiento.

En adición a lo anterior, la legislación contempla la posibilidad de que, en las calamidades de los apartados a) y b) del artículo 4 LOEAES, la autoridad competente pueda también adoptar, dependiendo del caso, las medidas previstas en las normas para la lucha contra enfermedades infecciosas, la protección del medio ambiente, las relativas a materia de aguas y a protección frente a incendios forestales -artículo 12.1 LOEAES- ${ }^{31}$. Y, aunque se omitan los apartados c) y d) del mismo artículo 4 LOEAES, es obvio que también a

${ }^{30}$ Sobre la incorrecta interpretación que de dicho precepto se ha hecho en virtud del Real Decreto 926/2020, de 25 de octubre, delegando en las distintas comunidades autónomas la facultad práctica de determinar la regulación concreta del estado de alarma en cada respectivo territorio -restricciones de derechos fundamentales incluida-, vid. nota 49.

${ }^{31}$ Como bien apunta GARCÍA CUADRADO, A. M., "El estado de alarma y su ambigua naturaleza", en Cuadernos constitucionales de la Cátedra Fadrique Furió Ceriol, núm. 8, 1994, p. 99, "solo faltaría que, declarado el estado de alarma, no pudieran las autoridades gubernativas ejercer las potestades que el Ordenamiento les reconoce para casos de riesgo 0 calamidad pública". 
ellos les es aplicable la normativa sobre protección civil. Además, y precisamente en relación con esos supuestos c) y d), el artículo 12.2 LOEAES otorga al Gobierno la capacidad para intervenir empresas o servicios, así como la movilización de su personal, al objeto de asegurar su funcionamiento. Una regulación deficiente puesto que -al margen de que debería hacer referencia también a los apartados a) y b) del artículo 4 LOEAES-, si la intervención de empresas o servicios ya está contemplada en el artículo 11 LOEAES, la previsión de la movilización ${ }^{32}$ es rechazada por la principal doctrina, si por aquella se entendiese la posibilidad de someter al personal movilizado a la jurisdicción militar, algo que ya hemos visto solo es posible en el estado de sitio -artículo 117.5 CE-33.

Estudiada la regulación básica aplicable al estado de alarma en nuestro país, disponemos ya de los mimbres suficientes para determinar el mejor o peor uso que de dicha institución se ha realizado en las dos situaciones que han dado pie a su declaración: la crisis de los controladores aéreos -año 2010- y la pandemia por covid-19 -año 2020-.

\section{La crisis de los controladores aéreos como emergencia constitucional... ¿insuficientemente reglada?}

Refiriéndonos pues al primero de esos supuestos, hay que retrotraerse a finales del año 2010, cuando el conflicto laboral entre el colectivo de controladores aéreos y la Agencia Española de Navegación Aérea -AENAdesembocó en el colapso del tráfico aéreo del país, al abandonar aquellos sus puestos de trabajo de manera masiva.

Ante tal circunstancia -era además puente de la Constitución-, el Gobierno dictó el Real Decreto 1611/2010, de 3 de diciembre ${ }^{34}$, confiriendo al Ministerio de Defensa la facultad de control del tráfico aéreo. En el marco de esa maniobra, encargó al Jefe de Estado Mayor del Ejército del Aire la activación

\footnotetext{
32 Para ÁlVAREZ CONDE, E. y TUR AUSINA, R., Derecho Constitucional, 8ª edición, Tecnos, Madrid, 2018, p. 566, "quizás, la medida más drástica que puede provocar la declaración del estado de alarma".

${ }^{33}$ BERDUGO GÓMEZ DE LA TORRE, I., "Garantías en la Constitución ante la suspensión de Ios derechos fundamentales", en Sistema: Revista de Ciencias Sociales, núm. 42, 1981, p. 11; CRUZ VILLALÓN, P., Estados excepcionales y suspensión de garantías, op. cit., p. 79; y ÁLVAREZ CONDE E., y TUR AUSINA, R., Derecho Constitucional, op. cit., p. 569.

${ }^{34}$ Real Decreto 1611/2010, de 3 de diciembre, por el que se encomienda transitoriamente al Ministerio de Defensa las facultades de control de tránsito aéreo atribuidos a la entidad pública empresarial AENA.
} 
de los recursos en materia de control del tráfico aéreo propios del Ministerio de Defensa, así como la impartición a los controladores aéreos de la orden de regresar a sus puestos de trabajo.

No obstante, el Ejecutivo se encontró con un problema no advertido antes. Pese a que la legislación vigente ${ }^{35}$ contemplaba dicha atribución competencial al Ministerio de Defensa, cosa distinta cabe decir del sometimiento de los controladores, en cuanto que personal civil, al mando del Jefe de Estado Mayor del Ejército del Aire. Ello llevó al Gobierno a aprobar el Real Decreto 1673/2010, de 4 de diciembre ${ }^{36}$, de declaración del estado de alarma, por el cual se confería a todos los controladores al servicio de AENA la consideración de personal militar. Las medidas asociadas a dicho estado se proyectaron sobre todo el territorio nacional, afectando por tanto a todos los controladores aéreos integrados en AENA.

El estado de alarma se declaró por un período inicial de quince días, al cual le siguió otro plazo adicional de otros treinta, consecuencia de la prórroga decretada por el Gobierno, vía Real Decreto 1717/2010, de 17 de diciembre ${ }^{37}$, previa autorización del Congreso de los Diputados dispensada en sesión de 16 de diciembre ${ }^{38}$. En suma, el estado de alarma se mantuvo en vigor desde el 4 de diciembre hasta las veinticuatro horas del 15 de enero del año $2011^{39}$.

Descritos brevemente los hechos sucedidos, es hora de analizar jurídicamente la aplicación de un estado de alarma que, a la vista está, resultó eficaz a la

\footnotetext{
${ }^{35}$ Por entonces, el artículo 4.4 de la Ley 21/2003, de 7 de julio, de Seguridad Aérea, disponía que "El Ministerio de Defensa ejercerá siempre el control de la circulación aérea operativa y, en tiempos de conflicto armado, el control de la circulación aérea general. También ejercerá el control de la circulación aérea general en los siguientes casos: a) Cuando el Presidente del Gobierno decida que esta competencia sea ejercida por el Ministerio de Defensa, por concurrir circunstancias extraordinarias que así lo aconsejen. b) Cuando se den situaciones de emergencia, declaradas por el Ministerio de Defensa". Hoy día, y aunque con redacción diferente, el artículo 4 de la misma Ley sigue habilitando al Ministerio de Defensa para el ejercicio de las competencias asumidas en el año 2010.

${ }^{36}$ Real Decreto, 1673/2010, de 4 de diciembre, por el que se declara el estado de alarma para la normalización del servicio público esencial del transporte aéreo.

${ }^{37}$ Real Decreto 1717/2010, de 17 de diciembre, por el que se prorroga el estado de alarma declarado por el Real Decreto 1673/2010, de 4 de diciembre.

${ }^{38}$ Resolución de 16 de diciembre de 2010, del Congreso de los Diputados, por la que se ordena la publicación del acuerdo de autorización de la prórroga del estado de alarma declarado por el Real Decreto 1673/2010, de 4 de diciembre.

39 Superada la situación de urgencia, el Gobierno devolvió a AENA las competencias de dirección del control de la circulación aérea general al Ministerio de Defensa -Real Decreto 28/2011, de 14 de enero, por el que se deroga el Real Decreto 1611/2010, de 3 de diciembre, por el que se encomienda transitoriamente al Ministerio de Defensa las facultades de control de tránsito aéreo atribuidos a la entidad pública empresarial AENA-.
} 
hora de dar solución a la situación de crisis generada ${ }^{40}$. Pues bien, partiendo de la no adecuación de la actuación gubernamental a lo establecido en la Constitución y en la LOEAES, nosotros abordaremos el asunto a partir de las siguientes preguntas: ¿constituyó la crisis de los controladores aéreos un supuesto de emergencia constitucional no reglada o insuficientemente reglada? $Y$ en consecuencia ¿cabe invocar el derecho de necesidad para justificar las medidas impuestas bajo el estado de alarma?

Para resolver dichas cuestiones, lo primero es especificar brevemente -pues sobre la cuestión ya hay mucho escrito ${ }^{41}$ - por qué la respuesta estatal dispensada frente a la crisis aérea carecía de soporte jurídico si atendemos a la literalidad del artículo 116 CE y a su legislación de desarrollo. En este sentido, simplemente recordar que: 1) No concurrían los presupuestos habilitantes del artículo 4 LOEAES pues, en contra de lo argumentado por el Gobierno en el artículo 1 del Real Decreto 1673/2010, ni se produjo alguno de los desastres contemplados en el apartado a), ni existía una situación de desabastecimiento de productos de primera necesidad, que es lo que exige el apartado d ${ }^{42}$; 2) El artículo 117.5 CE reserva exclusivamente al estado de sitio la posibilidad de que el personal civil pueda ser sometido a la jurisdicción militar $^{43}$. 3) La prórroga decretada por un mes lo fue ante "una situación de

\footnotetext{
${ }^{40}$ Pero, siguiendo a REQUEJO RODRÍGUEZ, P., "Teoría vs. práctica del estado de alarma en España", en Constitución y democracia: ayer y hoy. Libro homenaje a Antonio Torres del Moral, vol. II, Universitas, 2012, p. 1505 , "de lo que se trata aquí es de valorar no la eficacia, sino la corrección jurídica de las medidas acordadas".

${ }^{41}$ Empezando por VERA SANTOS, J. M., "Secesión y derecho de excepción. A vueltas con el estado de alarma en España", en Consecuencias jurídicas de la secesión de entidades territoriales. Una visión para España, Thomson Reuters-Aranzadi, Navarra, 2020, pp. 433-486; ABA CATOIRA, A., "El concepto jurisprudencial de límite de los derechos fundamentales", en Anuario da Facultade de Dereito, núm. 2, 1998, pp. 13-31; REQUEJO RODRíGUEZ, P., "Teoría vs. Práctica del estado de alarma en España", op. cit., pp. 1499-1513; y VIDAL PRADO, C. y DELGADO RAMOS, D., "Algunas consideraciones sobre la declaración del estado de alarma y su prórroga", en Revista Española de Derecho Constitucional, núm. 92, mayo-agosto 2011, pp. 243-265.

42 Además, bien está volver a recordar que, cuando el artículo 4 c) LOEAES prevé la "paralización de servicios públicos esenciales para la comunidad" como un supuesto de hecho que justificaría la declaración del estado de alarma, lo hace bajo la condición de que "no se garantice lo dispuesto en los artículos veintiocho, dos, y treinta y siete, dos, de la Constitución, y concurra alguna de las demás circunstancias o situaciones contenidas en este artículo". En el caso que nos ocupa, en ningún momento se declaró formalmente una huelga y menos, por tanto, una en la que no se garantizasen unos servicios mínimos consensuados.

${ }^{43}$ Artículo 117.5 CE: "El principio de unidad jurisdiccional es la base de la organización y funcionamiento de los Tribunales. La ley regulará el ejercicio de la jurisdicción militar en el ámbito estrictamente castrense y en los supuestos de estado de sitio, de acuerdo con los principios de la Constitución".
} 
incertidumbre"44, pese a que el preámbulo del Real Decreto 1717/2010 aseguraba que el servicio de control del tráfico aéreo se prestaba ya "en condiciones de normalidad" -aunque es cierto que negando, a continuación, que el funcionamiento del sistema aeroportuario fuera "idéntico al de situaciones de normalidad anteriores"- 45 .

Una vez constatada la incompatibilidad entre la literalidad de la regulación y las medidas efectivamente establecidas, es hora de dar respuesta a las dos preguntas antes planteadas. Pues bien, en nuestra opinión, la crisis aérea producida no puede enmarcarse dentro de la figura de la emergencia constitucional no reglada o insuficientemente reglada, lo cual impide la validación de la actuación gubernamental a través de la invocación del derecho de necesidad.

Para alcanzar tal conclusión, partimos de la base de que la grave alteración en el normal funcionamiento del tráfico aéreo, en cuanto que servicio público esencial para la comunidad, sin ninguna circunstancia adicional, no encaja en el estado de alarma sino en el de excepción -artículo 13.1 LOEAES $^{46}$. . A partir de ahí, resulta vano preguntarse acerca de la imprescindibilidad o no de decretar la militarización de los controladores aéreos - ¿era suficiente con la legislación civil ${ }^{47}$ o no había alternativa a una medida que, no estando prevista

\footnotetext{
${ }^{44}$ Son palabras del por aquel entonces Ministro de la Presidencia, Señor Ramón Jáuregui Europapress, 16 de diciembre de 2010, edición digital, consultada el 6 de diciembre de 2020, https://www.europapress.es/nacional/noticia-jauregui-mera-incertidumbre-tiene-costeinasumible-20101216130207.html-.

${ }^{45}$ También habría revestido una evidente inconstitucionalidad ex artículo 55.1 CE el hecho de recurrir al estado de alarma para suspender un derecho a la huelga que, como ya se ha apuntado en la nota 41, no fue formalmente invocado por los controladores aéreos. Se trató, más bien, de una huelga encubierta, y ello porque los controladores aéreos no siguieron las formalidades previstas en el Real Decreto-ley 17/1977, de 4 de marzo, sobre relaciones de trabajo, por ejemplo, a efectos de comunicar a AENA o al Ministerio de Defensa la decisión de declarar la huelga, previamente acordada de manera expresa -artículo 3-. Más al respecto en SEDANO LORENZO, A., El estado de alarma y la justicia militar. A propósito de la crisis de controladores aéreos, Liber Factory, Madrid, 2015, pp. 109 y 110.

${ }^{46}$ Artículo 13.1 LOEAES: "Cuando el libre ejercicio de los derechos y libertades de los ciudadanos, el normal funcionamiento de las instituciones democráticas, el de los servicios públicos esenciales para la comunidad, o cualquier otro aspecto del orden público, resulten tan gravemente alterados que el ejercicio de las potestades ordinarias fuera insuficiente para restablecerlo y mantenerlo, el Gobierno, de acuerdo con el apartado tres del artículo ciento dieciséis de la Constitución, podrá solicitar del Congreso de los Diputados autorización para declarar el estado de excepción". A favor de la declaración del estado de excepción en esta situación, VERA SANTOS, J. M., "The notion of exception in the Spanish Constitution of 1978: Theory and Practice", en The legal implications of territorial secession in Spain, Springer Verlag, Heidelberg, 2021, apartado 3.1. (en prensa, con títulos provisionales).

47 Por ejemplo, el artículo 4.4 de la Ley $2 / 1985$, de 21 de enero, sobre protección civil, establecía que: "en los casos de grave riesgo, catástrofe o calamidad pública, todos los
} 
para el estado de alarma, quedaría entonces justificada por el estado de necesidad?-. La ilegalidad de esa actuación es insalvable desde el momento en el que fue impuesta vía estado de alarma y no bajo el paraguas de un estado de excepción que, eso sí, habría requerido la urgente reunión del Congreso de los Diputados para que su autorización no llegara demasiado tarde. Pero, es que, tratar de validar el estado de alarma, invocando para ello su mayor agilidad en comparación con el estado de excepción, esconde un problema potencialmente mayor que el que habría supuesto prolongar la parálisis del espacio aéreo hasta el momento de la autorización parlamentaria. Lo que se consigue con ese enfoque es la relativización de la normativa de excepción aplicable en nuestro país -la norma es clara en lo que a los supuestos de hecho se refiere y, si no gusta, debe cambiarse-, con los peligros que ello conlleva para el orden constitucional establecido.

Por lo demás, y respecto a la prórroga decretada, ya decíamos que la LOEAES no contempla el estado de alarma para situaciones de mera incertidumbre ${ }^{48}$. Porque, como se ha visto también, su artículo 1.2 es claro cuando exige que, tanto aquellas como su duración, sean siempre las estrictamente imprescindibles para asegurar la vuelta a la normalidad, debiendo igualmente ser aplicadas de manera proporcionada a las circunstancias. Por eso, si el tráfico aéreo -cuyo colapso fue la causa exclusiva de la activación del estado de alarma- había recobrado realmente la normalidad, la decisión de la prórroga no se ajustó a la ley. Salvo que tal normalidad no existiera, pero entonces habría sido necesaria mayor claridad por parte del Gobierno, evitando incurrir en la contradicción ya señalada. En cualquier caso, es posible que una interpretación amplia de la normativa por parte del Tribunal Constitucional hubiera servido para validar la medida.

Finalmente, y en lo que a la duración de la prórroga se refiere -un mes-, la indefinición del artículo 116.2 CE vuelve a conceder un importante margen de discrecionalidad a dicho Tribunal a la hora resolver la cuestión. En cualquier caso, nosotros nos remitimos a las consideraciones que haremos en el

residentes en territorio nacional estarán obligados a la realización de las prestaciones personales que exija la autoridad competente, sin derecho a indemnización por esta causa, y al cumplimiento de las órdenes generales o particulares que dicte". Dicha norma fue expresamente derogada por la Ley 17/2015, de 9 de julio, del Sistema Nacional de Protección Civil.

${ }_{48}$ PULIDO QUECEDO, M., "La prórroga del estado de alarma "por incertidumbre"', en Actualidad jurídica Aranzadi, núm. 813, 2011, p. 17. 
apartado III.4., al referirnos a la prórroga de seis meses decretada sobre el tercer y último estado de alarma declarado en el año 2020 contra la covid-19.

En definitiva, y recapitulando. El estado de alarma declarado en el año 2010 fue contrario a Derecho. De tener que acudir al artículo 116 CE por revelarse insuficiente la legislación ordinaria, debería haberse optado por el estado de excepción, siendo el sometimiento de los controladores aéreos al fuero militar una actuación cuya constitucionalidad se habría podido salvar, entonces quizás sí -y solo en caso de que no existiera alternativa menos gravosa a esa medida-, invocando el derecho de necesidad ${ }^{49}$.

\section{El elemento no reglado en la crisis sanitaria por covid-19}

Centrándonos ahora en el recurso al estado de alarma con motivo de la pandemia por covid-19, razones de espacio nos obligan a analizar únicamente aquellos aspectos que inciden de manera directa en la cuestión que aquí nos ocupa. Esto es, hasta qué punto el ordenamiento jurídico estaba o no preparado, por lo preciso o impreciso de la regulación, para hacer frente a una amenaza cuya entidad ha requerido la aplicación de ciertas medidas cuya entidad ni el constituyente ni el legislador acertaron a prever.

Dejando a un lado, por lo tanto, la alusión a importantes disfuncionalidades en cuestiones que no deberían generar especial discusión ${ }^{50}$, y siguiendo un orden

\footnotetext{
${ }^{49}$ Una razón adicional para creer en la conveniencia del estado de excepción en este caso radica en el hecho de que, siguiendo a CRUZ VILLALÓN, P., Estados excepcionales y suspensión de garantías, op. cit., p. 122, ese sometimiento a la jurisdicción militar equivale para los ciudadanos afectados, "si no en la forma sí en el fondo, a una suspensión del artículo 24.2 de la Constitución, el derecho al Juez ordinario predeterminado por la ley". De igual opinión, LAFUENTE BALLE, J. M., "Los estados de alarma, excepción y sitio (II)", op. cit., p. 64.

${ }^{50}$ Nos referimos, por ejemplo, al incumplimiento del artículo 116.5 CE, tras la parálisis inicial del Congreso de los Diputados una vez se declaró el estado de alarma en marzo -vid. VIDAL PRADO, C., "El Congreso no puede hibernar", en El Mundo, 6 de abril de 2020-; al abuso de la técnica de la auto remisión a órdenes ministeriales sanitarias a la hora de regular derechos fundamentales durante lo que se vino a llamar "desescalada" -vid. VERA SANTOS, J. M., "Secesión y derecho de excepción. A vueltas con el estado de alarma en España", op. cit., pp. 480 y ss.-; a los excesos competenciales igualmente protagonizados por los ejecutivos autonómicos al restringir derechos fundamentales, una vez decayó el primer estado de alarma TAJADURA TEJADA, J., "Uso de mascarilla y "reserva de ley"”, El País, 22 de julio de 2020-; en esa misma línea, a la aplicación, vía Real Decreto 926/2020, de 25 de octubre, de un estado de alarma -o estados de alarma de "declaración autonómica por delegación", como los describe ARAGÓN REYES, M., "La prórroga del estado de alarma", en El País, 28 de octubre de 2020-, en virtud del cual, "el Gobierno ha delegado en las comunidades autónomas facultades que no pueden ser transferidas: la de establecer los requisitos en virtud de los cuales se puede restringir un derecho fundamental y la de adoptar unilateralmente la restricción" -TAJADURA TEJADA, J., "Estado de alarma y seguridad jurídica", en El País, 27 de octubre de 2020-; o, por
} 
fundamentalmente cronológico de los hechos, comenzaremos atendiendo al asunto que mayor división ha suscitado entre la doctrina. Nos referimos a los vicios de inconstitucionalidad derivados del recurso a la figura del estado de alarma para suspender de manera general derechos fundamentales -libre circulación del artículo 19 CE a la cabeza- ${ }^{51}$, principalmente a raíz de la imposición de confinamientos generales casi totales de la población.

Relacionado igualmente con la protección de los derechos fundamentales, hablaremos brevemente de dos tipos de medidas que, no estando contempladas de ningún modo en el ordenamiento jurídico, devinieron en una importante restricción de aquellos: de un lado, las afectaciones sobre el derecho de sufragio, ello con motivo de la suspensión y celebración final -el 12 de julio- de las elecciones autonómicas gallegas y vascas; y de otro, las restricciones obradas sobre la libertad de empresa -artículos 37 y $38 \mathrm{CE}$ - tras el cierre casi total de los comercios, ello a pesar de no estar ya vigentes los confinamientos tan intensos y generalizados de principios de año -es decir, nos fijamos en la restricción producida de manera desligada a esos aislamientos iniciales- ${ }^{52}$.

Finalmente, concluiremos haciendo referencia a un aspecto que afecta también de lleno a la estructura del derecho de emergencia constitucional en España: la decisión adoptada en el tercer y último de los estados de alarma declarados en el año 2020, en el sentido de prorrogarlo por un período de seis meses, haciendo con ello imposible el adecuado control de los poderes extraordinarios del Gobierno a manos del Congreso de los Diputados.

\footnotetext{
último, al hecho de que el artículo 2.3 del Real Decreto 926/2020, de 25 de octubre, exima a los ejecutivos autonómicos de la obligación de ratificación judicial de las medidas restrictivas adoptadas por las autoridades, cuando es lo exigido en los artículos 8.6 -párrafo segundo- y 10.8 de la Ley 29/1998, de 13 de julio, reguladora de la Jurisdicción Contenciosoadministrativa.

${ }^{51}$ Como bien señala DÍAZ REVORIO, F. J., "A vueltas con la suspensión de los derechos fundamentales", en Almacén de derecho, 9 de abril de 2020, acceso el 15 de septiembre de 2020, https://almacendederecho.org/a-vueltas-con-la-suspension-de-los-derechosfundamentales/, p. 3 , la afectación a otros derechos fundamentales no será más que una "consecuencia ineludible de las medidas adoptadas respecto a la libertad de circulación". Además, y para mayor precisión terminológica, habrá que estar al caso concreto a la hora de determinar si la medida de suspensión en concreto afecta a los derechos y/o a las garantías. Más sobre la cuestión, en DE LA QUADRA-SALCEDO FERNÁNDEZ DEL CASTILLO, T., «La naturaleza de los derechos fundamentales en situaciones de suspensión», en Anuario de Derechos Humanos, núm. 2, 1983, pp. 452 y ss.

${ }^{52}$ Por lo tanto, cuando las afectaciones sobre la libertad de empresa no son estrictamente consecuencia de las afectaciones sobre la libre circulación, sino que constituyen una medida complementaria. Vid. primera parte de la nota al pie anterior.
} 
Pero antes de eso, y a los efectos de una adecuada contextualización, recordemos muy brevemente el orden de sucesión de los hechos. El 14 de marzo, y ante la rápida expansión del covid-19 en España, entraba en vigor el Real Decreto $463 / 2020^{53}$, en lo que fue el inicio de unas restricciones en materia de derechos fundamentales sin parangón en la Unión Europea ${ }^{54}$. Ese estado de alarma se prolongaría hasta la media noche del 21 de junio ${ }^{55}$, momento a partir del cual los ejecutivos autonómicos asumieron el protagonismo en la lucha contra la pandemia. Finalizado el verano, el Gobierno decidía decretar un nuevo estado de alarma, esta vez solo sobre la Comunidad Autónoma de Madrid -Real Decreto 900/2020, de 9 de octubre ${ }^{56}$, al que le seguiría una nueva declaración del estado de alarma, de nuevo ya sobre todo el territorio nacional -Real Decreto 926/2020, de 25 de octubre- ${ }^{57}$. Al cierre de este trabajo ${ }^{58}$, y como consecuencia de la prórroga de seis meses acordada por el Congreso de los Diputados ${ }^{59}$, se prevé que este tercer y último estado de alarma se mantenga vigente hasta la medianoche del 9 de mayo de 2021.

\section{A) ¿Estado de alarma o estado de excepción?}

Dicho lo cual, toca centrarnos ya en la cuestión medular de lo sucedido durante la lucha contra la pandemia en nuestro país, ello si de derecho constitucional

${ }^{53}$ Real Decreto 463/2020, de 14 de marzo, por el que se declara el estado de alarma para la gestión de la situación de crisis ocasionada por el COVID-19.

${ }^{54}$ Solo el caso italiano podría ser equiparable, siendo el propio Gobierno español el que, a través de su Ministro de Sanidad, reconocía que "España ha tenido el confinamiento más duro de los países de la Unión Europea"

https://www.mscbs.gob.es/profesionales/saludPublica/ccayes/alertasActual/nCov-

China/videosPrensa.htm, comparecencia de 2 de junio de 2020-.

${ }^{55}$ Al Real Decreto 463/2020, de 14 de marzo, por el que se declara el estado de alarma para la gestión de la situación de crisis ocasionada por el COVID-19, le siguieron los Reales Decretos 465/2020, de 17 de marzo; 476/2020, de 27 de marzo; 487/2020, de 10 de abril; 492/2020, de 24 de abril, 514/2020, de 8 de mayo; 537/2020, de 22 de mayo; y 555/2020, de 5 de junio, ello sin perjuicio de que en algunas Comunidades Autónomas las medidas a él asociadas decayeran unos días antes.

${ }^{56}$ Real Decreto 900/2020, de 9 de octubre, por el que se declara el estado de alarma para responder ante las situaciones de especial riesgo por transmisión no controlada de infecciones causadas por el SARS-CoV-2.

${ }^{57}$ Real Decreto $926 / 2020$, de 25 de octubre, por el que se declara el estado de alarma para contener la propagación de infecciones causadas por el SARS-CoV-2.

${ }^{58}$ Enviado para su publicación el 22 de diciembre de 2020.

59 Vía Resolución de 29 de octubre de 2020, del Congreso de los Diputados, por la que se ordena la publicación del Acuerdo de autorización de la prórroga del estado de alarma declarado por el Real Decreto 926/2020, de 25 de octubre, por el que se declara el estado de alarma para contener la propagación de infecciones causadas por el SARS-CoV-2. Dicho Acuerdo se tradujo en la aprobación del Real Decreto 956/2020, de 3 de noviembre, por el que se prorroga el estado de alarma declarado por el Real Decreto 926/2020, de 25 de octubre, por el que se declara el estado de alarma para contener la propagación de infecciones causadas por el SARS-CoV-2. 
hablamos. Se han suspendido derechos fundamentales prescindiendo para ello de los cauces constitucionales establecidos, toda vez que, como veíamos antes, el estado de alarma no contempla restricciones de tamaña intensidad -artículo 55.1.CE-.

Ahora bien, no se trata esta de una cuestión pacífica, ni mucho menos. De hecho, desde una parte muy importante de la doctrina se defiende la constitucionalidad de las medidas gubernamentales adoptadas en materia de derechos fundamentales vía estado de alarma, partiendo para ello de la existencia de una "afectación drástica del principio general de libertad" consagrado en el artículo $1.1 \mathrm{CE}^{60}$. Desde esa lógica, ya no tendría sentido discutir acerca de la naturaleza jurídica de las restricciones impuestas - ¿ordinaria limitación o suspensión?-. Rebasado el marco constitucional ${ }^{61}$, el estado de necesidad se abriría paso ${ }^{62}$, siendo el respeto al principio de proporcionalidad y a los principios generales del derecho ${ }^{63}$ la referencia jurídica que debiera guiar la actuación estatal frente al peligro concreto.

La cuestión es que, lejos de tratarse de un evento por completo ajeno a nuestro ordenamiento jurídico, la posibilidad de que una crisis sanitaria provocada por un virus condicionara nuestra forma de vida fue anticipada por el legislador hace ya casi cuarenta años -el artículo 4 LOEAES así lo demuestra-. ¿Qué la regulación podía haber sido más precisa? Es evidente, pero probablemente porque nunca se pensó que una crisis sanitaria pudiera alcanzar tal intensidad. De ahí que algunas de las medidas que se ha decidido adoptar frente a la pandemia no estén previstas en ningún caso.

En efecto, el ordenamiento jurídico español yerra ya en relación con la principal de las restricciones impuestas sobre los derechos fundamentales: el confinamiento casi total de la población. No se contempla ni siquiera para los estados de excepción y de sitio, en la medida en que el artículo 20 LOEAES

\footnotetext{
${ }^{60}$ CRUZ VILLALÓN, P., "La Constitución bajo el estado de alarma", en El País, 17 de abril de 2020. De la misma opinión; DE LA QUADRA-SALCEDO, T., "Límite y restricción, no suspensión", en El País, 8 de abril de 2020.

${ }^{61}$ PÉREZ ROYO, J., "Estado de excepción material", en Eldiario.es, 12 de marzo de 2020, https://www.eldiario.es/contracorriente/excepcion-material_132_1001921.html.

${ }^{62}$ CRUZ VILLALÓN, "La Constitución bajo el estado de alarma", op. cit.

${ }^{63}$ DE LA QUADRA-SALCEDO, T., "Límite y restricción, no suspensión", op. cit.; y LÓPEZ GARRIDO, D., "Un estado de excepción sería inconstitucional", en Eldiario.es, 11 de abril de 2020, acceso el 1 de julio de 2020, https://www.eldiario.es/tribunaabierta/excepcioninconstitucional_6_1015658433.html; y CRUZ VILLALÓN, P., "La Constitución bajo el estado de alarma", op. cit.
} 
habla simplemente de la posibilidad de "prohibir la circulación de personas y vehículos en las horas y lugares que se determine"64. Pero ya sabemos que no fue eso lo sucedido durante lo peor de la pandemia, con una libertad de circulación impedida salvo para contadas excepciones -se impuso un principio general de prohibición-, ello en virtud de lo dispuesto en el artículo 7.1 del Real Decreto $463 / 2020$, de 14 de marzo 65 .

Ahora bien, ese exceso interpretativo no tiene por qué suponer la automática inconstitucionalidad de la medida. $Y$, es que, como ya apuntamos antes, resulta perfectamente razonable defender la coexistencia entre la aplicación de la regulación positiva de los estados excepcionales -por momentos desbordada- y la aplicación del derecho de necesidad, uno de cuyos fundamentos principales veíamos que es el respeto al principio de proporcionalidad en la medida adoptada. El problema es que la combinación de estados de emergencia constitucional, de un lado, y derecho de necesidad, de otro, no ha resultado la deseada. En lugar de partir del estado de alarma, debería haberse optado por la declaración del estado de excepción, por ser el instrumento jurídico más ajustado -o menos desajustado, según se quiera ver- a las circunstancias concurrentes, ello desde el momento en el que las medidas del artículo 4 LOEAES se revelaron insuficientes para atajar la crisis sanitaria producida.

Porque, como ya hemos deslizado hace escasas líneas, la decisión de confinar a la población en sus casas, por muy proporcionada que pudiera ser, constituye una auténtica suspensión de derechos fundamentales no permitida en vigencia del estado de alarma -artículo 55.1 CE-. Y, es que, para hablar de suspensión no es necesario que el derecho fundamental restringido desaparezca por completo, sino que basta con afectar a su contenido esencial $^{66}$, algo que evidentemente sucedió. Solo tras determinar el respeto o

\footnotetext{
${ }^{64}$ Apúntese simplemente que, en virtud del artículo 32.3 LOEAES, la declaración del estado de sitio permite la adopción de las medidas previstas para los estados de alarma y de excepción, amén de la suspensión temporal de las garantías jurídicas del detenido que se reconocen en el apartado 3 del artículo 17 CE.

${ }_{65}$ Incluidas sus posteriores modificaciones vía Reales Decretos 465/2020, de 17 de marzo; y 514/2020, de 8 de mayo. En esa línea, ARAGÓN REYES, M., "Hay que tomarse la Constitución en serio", en El País, 13 de abril de 2020; VERA SANTOS, J. M., "Estado de alarma: tarde y mal", en El Independiente, 19 de marzo de 2020, acceso el 29 de septiembre de 2020, https://www.elindependiente.com/opinion/2020/03/19/estado-de-alarma-tarde-y-mal/; y DÍAZ REVORIO, F. J., Cosas de juristas, 19 de marzo de 2020, acceso el 16 de julio de 2020, http://revorio.blogspot.com/2020/03/cosas-de-juristas.html.

${ }^{66}$ Circunstancia que, según el Tribunal Constitucional, se produce bien cuando la norma reguladora del derecho lo convierta en irreconocible, o bien cuando se le someta a tamañas restricciones que su ejercicio sea imposible o más difícil de lo razonable, o se le despoje de la
} 
no al mismo -así como la correcta utilización de los mecanismos constitucionales establecidos para cada tipo de restricción-, y solo entonces, procederá valorar si la medida en cuestión fue proporcionada dadas las circunstancias concretas ${ }^{67}$.

Por todo ello, debería haberse optado por el estado de excepción, contemplado, como veíamos al hablar de la crisis aérea, para supuestos de grave alteración del orden público, entre los cuales se alude expresamente al "normal funcionamiento $(. .$.$) de los servicios públicos esenciales para la$ comunidad" -artículo 13.1 LOEAES $^{68}$. Y la situación de anormal funcionamiento de los hospitales, en riesgo de colapso durante ese tiempo, era evidente, tal y como llegó a reconocer el propio Presidente del Gobierno ${ }^{69}$.

Sentado lo cual, y frente a quienes niegan la improcedencia del estado de excepción al entender que los problemas hospitalarios no son calificables como alteraciones del orden público, por no revestir naturaleza política ${ }^{70}$, la principal doctrina nos recuerda que "el significado jurídico del término «orden público» no se identifica solo con el orden público político o institucional, sino que engloba también el orden público social y económico" ${ }^{\prime 71}$. Pues bien, basta con

necesaria protección -STC 11/1981, de 8 de abril, FJ 8-. Sobre la cuestión, vid. La defensa de la Constitución. El derecho de emergencia constitucional y el artículo 55 CE, op. cit., pp. 235 y ss.

${ }^{67}$ Discrepamos, por lo tanto, de quienes fían el diagnóstico sobre la constitucionalidad de la medida impuesta a la exclusiva aplicación del principio de proporcionalidad -vid. CRUZ VILLALÓN, P., "La Constitución bajo el estado de alarma", op. cit.; DE LA QUADRASALCEDO, T., "Límite y restricción, no suspensión", op. cit.; y LÓPEZ GARRIDO, C., "Un estado de excepción sería inconstitucional", op. cit.-.

${ }^{68}$ Defienden la declaración del estado de excepción, por ejemplo, VERA SANTOS, J. M., "Estado de alarma: tarde y mal", en El Independiente, 19 de marzo de 2020, acceso el 29 de junio de 2020, https://www.elindependiente.com/opinion/2020/03/19/estado-de-alarma-tarde-ymal/; DÍAZ REVORIO, F. J., Cosas de juristas, op. cit.; ARAGÓN REYES, "Hay que tomarse la Constitución en serio", op. cit.; y CUENCA MIRANDA, A., «Alarma "excepcional"», en Papeles FAES, núm. 236, 2020, p. 5.

${ }^{69}$ Por ejemplo, al afirmar que "podemos salvar a muchas personas con los medios adecuados, y lo tenemos más difícil si la avalancha colapsa el sistema"; o que "si reducimos los contagios los hospitales podrán evitar el colapso y curar a una gran cantidad de personas" Comparecencia del Presidente del Gobierno desde el Palacio de la Moncloa, de 21 de marzo de 2020, acceso el 2 de diciembre de 2020, https://www.lamoncloa.gob.es/presidente/intervenciones/paginas/2020/prsp21032020.aspx-.

${ }^{70}$ Entre otros, CRUZ VILLALÓN, P., "La Constitución bajo el estado de alarma", op. cit., DE LA QUADRA-SALCEDO, T., "La aversión europea al estado de excepción", en El País, 28 de abril de 2020; y LÓPEZ GARRIDO, C., "Un estado de excepción sería inconstitucional", op. cit.

${ }^{71}$ "Y así se ha entendido siempre por la más autorizada doctrina del Derecho Público desde hace más de un siglo", tal y como subraya ARAGÓN REYES, M., "Dos precisiones", en El País, 18 de abril de 2020. Por eso, para el profesor resulta "razonable sostener que la gravísima y profunda afectación de las condiciones de vida de la comunidad, que es lo que ha producido la insólita pandemia que hoy asola a España y al mundo, es algo bien distinto de las crisis 
apuntar que esos dos últimos elementos -el social y el económico- fueron expresamente mencionados incluso por el propio Gobierno en el preámbulo del Real Decreto 463/2020, de 14 de marzo ${ }^{72}$.

¿Que no estaba en el ánimo del constituyente el utilizar el estado de excepción para enfrentar amenazas con origen inicial en pandemias? El caso es que, aunque así fuera, lo auténticamente relevante es la voluntad última del propio constituyente de sentar una serie de premisas básicas e inamovibles frente a las situaciones de emergencia constitucional previstas en el artículo $116 \mathrm{CE}$. Y claro está, entre esas reglas elementales se encuentra el control parlamentario previo a la imposición de medidas en materia de suspensión de derechos fundamentales ${ }^{73}$. Por lo tanto, y ante una medida de semejante envergadura no prevista en el ordenamiento jurídico ¿cuál de las dos opciones se ajusta mejor a la voluntad del constituyente? ¿el recurso a un estado de alarma exacerbado y sin fiscalización parlamentaria durante quince días o el estado de excepción, controlado desde el primer momento? Para nosotros está perfectamente claro, nos quedamos con esta segunda opción.

Por todo lo anterior, somos de la opinión de que el confinamiento casi total impuesto bajo el paraguas del Real Decreto 463/2020, de 14 de marzo, supone una auténtica actuación contra constitutionem, por no ajustarse a las reglas jurídicas básicas establecidas en nuestro Texto fundamental para situaciones

sanitarias, tales como las epidemias, a las que se refiere el artículo 4.b de la Ley Orgánica 4/1981 dedicado al estado de alarma, y entra de lleno en el supuesto de hecho previsto para los estados de excepción en el artículo 13.1 de esa ley, cuyo texto me parece que no plantea grandes dudas para llegar a esta conclusión". Igualmente, favorable a interpretar el concepto de "orden público" más allá de la dimensión política, SERRANO ALBERCA, J. M., "Artículo 116", en GARRIDO FALLA, F. (dir.) Comentarios a la Constitución, Civitas, Madrid, 1985, p. 1787, cuando afirma que los supuestos de alteración del orden público previstos en relación con el estado de excepción han de tener "un origen político o social normalmente de carácter interno". También, VERA SANTOS, J. M., "Secesión y derecho de excepción. A vueltas con el estado de alarma en España", op. cit., p. 478, cuando habla de una situación de "auténtica crisis social". Y aunque incomprensiblemente no lo aplica a la crisis del covid-19, CRUZ VILLALÓN, P., Estados excepcionales y suspensión de garantías, op. cit., p. 86, señala que la alusión del artículo 13.1 LOEAES a la grave alteración en el normal funcionamiento de los servicios esenciales para la comunidad "pone de manifiesto que una situación de ese tipo tiene el carácter de alteración del orden público". Es decir, justo lo que exige el estado de excepción.

72 En efecto, en el párrafo tercero del mencionado preámbulo se indica que las medidas previstas en el Real Decreto 463/2020 "se encuadran en la acción decidida del Gobierno para proteger la salud y seguridad de los ciudadanos, contener la progresión de la enfermedad y reforzar el sistema de salud pública. Las medidas temporales de carácter extraordinario que ya se han adoptado por todos los niveles de gobierno deben ahora intensificarse sin demora para prevenir y contener el virus y mitigar el impacto sanitario, social y económico".

${ }^{73}$ En esa línea, SERRANO ALBERCA, J. M., "Artículo 116", op. cit., p. 1771, recuerda que "eliminada expresamente la previsión del «estado de necesidad", los constituyentes consideraron que sólo un sistema de poderes tasados era aceptable". 
de emergencia constitucional. No porque se trate de una medida no prevista en el ordenamiento jurídico, sino porque el salto al estado de necesidad no se produjo a partir del instrumento más tuitivo de entre los disponibles dadas las circunstancias concurrentes, el estado de excepción ${ }^{74}$. Además, y respecto a las restricciones a la libre circulación en horario nocturno -los denominados "toques de queda"- impuestas en aplicación del Real Decreto 926/2020, de 25 de octubre, habrá que esperar a que el Tribunal Constitucional se pronuncie sobre qué debe entenderse por contenido esencial del derecho a la libre circulación ${ }^{75}$. Porque, amén de que son restricciones con difícil encaje en el artículo 11 a) LOEAES -concuerdan mucho mejor con el artículo 20.1 LOEAES, para el estado de excepción-, podrían ser, no ya ilegales, sino inconstitucionales, por contravenir lo establecido en el artículo $55.1 \mathrm{CE}^{76}$.

B) Las afectaciones al derecho de sufragio en las elecciones gallegas y vascas

Otro ejemplo claro de actuación contra constitutionem se encuentra en lo ocurrido con motivo de las elecciones gallegas y vascas, inicialmente previstas para el 5 de abril del año 2020. Y, es que, si materialmente justificada fue la decisión inicial de suspenderlas por motivos sanitarios ${ }^{77}$, ello a pesar de ser una medida no prevista a nivel constitucional ni en la Ley Orgánica 5/1985, de

\footnotetext{
${ }^{74}$ Como tampoco se ajustan al ordenamiento español los innumerables aislamientos y confinamientos sobre amplios núcleos de población decretados por los ejecutivos autonómicos -o, incluso, por alcaldes a través de simples bandos-, ello sobre la base de una norma, la Ley Orgánica 3/1986, de 14 de abril, de Medidas Especiales en Materia de Salud Pública, que está pensada para aplicarse solo sobre grupos de personas y espacios muy concretos. En esa línea, RUIZ ROBLEDO, A., "Respuestas legales al coronavirus", en El País, 14 de marzo de 2020; y VÍRGALA FORURIA, E., 14 de marzo de 2020, acceso el 20 de septiembre de 2020, https://www.elindependiente.com/politica/2020/03/14/las-autonomias-tomaron-medidasinconstitucionales-por-la-tardanza-de-sanchez-segun-expertos/.

${ }^{75}$ Algo parecido cabe predicar del establecimiento de cierres perimetrales, previstos en el artículo 20.2 LOEAS. En cualquier caso, y habiendo desaprovechado la ocasión de aclarar la cuestión cuando dictó el ATC 40/2020, de 30 de abril, no parece cercano el momento en el que el Alto tribunal resuelva finalmente sobre los recursos de inconstitucionalidad interpuestos por el grupo parlamentario de Vox contra distintos aspectos de los estados de alarma decretados vía Real Decreto 463/2020, de 14 de marzo, y Real Decreto 926/2020, de 25 de octubre.

76 Descarta rotundamente que el "toque de queda" constituya suspensión de derechos fundamentales, DÍAZ REVORIO, F. J., "Suspensión de derechos y límites constitucionales del estado de alarma", en el Seminario "Excepcionalidad y derecho: el estado de alarma a debate", organizado por la Fundación Manuel Giménez Abad, celebrado el 21 de octubre de 2020, acceso el 28 de noviembre, disponible en https://multimedia.cortesaragon.es/library/items/4724. 77 Otra cosa es la manera en que ello se hizo - a través de simples decretos autonómicos. En este sentido, RUIZ ROBLEDO, "Respuestas legales al coronavirus"...; y TAJADURA TEJADA, J., "Uso de mascarilla y "reserva de ley"”, op. cit.-.
} 
19 de junio, del régimen electoral general -LOREG-, lo contrario cabe afirmar en relación con la decisión de los ejecutivos autonómicos de impedir el ejercicio presencial del derecho de sufragio a todas aquellas personas que el día de los comicios -celebrados el 12 de julio- estuvieran infectadas por la covid-1978.

La prohibición en cuestión, no contemplada en ninguna norma ${ }^{79}$, supuso la vulneración del derecho de sufragio de las personas afectadas, pues no se establecieron procedimientos alternativos para que incluso las personas afectadas por el virus pudieran votar con seguridad. Téngase en cuenta, a este respecto, que cuando se volvieron a convocar las elecciones, era más que razonable esperar que pudieran darse ese tipo de problemas. Pero es que, además, y como bien se afirma desde la doctrina, la adopción de esas medidas alternativas "no es una opción, sino una obligación de cumplimiento inexcusable" 80 .

C) La suspensión general de la libertad de empresa tras el confinamiento general inicial

Como apuntábamos al comienzo de este apartado III.4., el fenómeno del cierre obligado de comercios para frenar los contagios se va a estudiar aquí de manera desvinculada a las restricciones más intensas impuestas sobre la libre circulación de personas. Es decir, nos fijaremos en los casos en los que dicha medida ha funcionado como complemento de las restricciones sobre la libre circulación, no cuando estas últimas afectaban indefectiblemente a otros derechos vinculados a ella, libertad de empresa incluida -artículos 37 y $38 \mathrm{CE}^{-81}$.

Pues bien, en virtud del estado de alarma declarado mediante Real Decreto 926/2020, de 25 de octubre, los ejecutivos de muchas comunidades

\footnotetext{
${ }^{78}$ En el caso gallego, la decisión del ejecutivo autonómico fue avalada en virtud de Acuerdo de la Junta Electoral Central de 9 de julio de 2020 -ratificado por ATS de 11 de julio de 2020-. En el supuesto vasco, el visto bueno se produjo mediante Resolución de la Presidencia de la Junta Electoral Central, de 11 de julio de 2020, confirmada posteriormente en Acuerdo de 17 de julio de 2020, dictado por el propio órgano de control electoral.

${ }^{79} \mathrm{Ni}$ debería estarlo nunca, señala PÉREZ ROYO, J., "Las elecciones vascas y gallegas deben ser anuladas", Eldiario.es, 12 de julio de 2020, acceso el 25 de agosto de 2020, https://www.eldiario.es/contracorriente/elecciones-vascas-gallegas-debenanuladas_132_6099631.html, al entender que es algo que solo cabría mediante sentencia judicial firme, ello "a menos que decidamos prescindir de la democracia como forma política".

80 Ibidem. En la misma línea, CARMONA CONTRERAS, A., "El fin no justifica los medios", El País, 16 de julio de 2020.

${ }^{81}$ Vid. nota 50.
} 
autónomas han procedido al cierre general casi total de la actividad comercial de sus territorios durante varias semanas, ello en ejercicio de las competencias que el artículo 2.2 del Real Decreto 926/2020 les confiere en tanto que autoridades competentes delegadas.

En este sentido, y al margen de la indebida técnica de delegación empleada ${ }^{82}$, no hemos querido pasar la ocasión para subrayar, aunque sea de pasada, el hecho de que esos cierres suponen una evidente afectación al contenido esencial de la libertad de empresa. Un derecho que, a pesar de no estar entre los más protegidos, sí se reconoce dentro del Capítulo II, siéndole por tanto de aplicación las garantías consagradas en el artículo 53.1 CE, respeto a su contenido esencial incluido. Pues bien, es evidente que cerrar de manera general la práctica totalidad de los bares y restaurantes de las comunidades autónomas afectadas excede lo que es la ordinaria limitación de derechos. Tratándose, por lo tanto, de una suspensión de derechos no contemplada en el artículo 55.1 CE, habríamos estado ante un nuevo ejemplo de lo que nosotros entendemos por derecho constitucional de excepción, aplicado ante emergencias no regladas o insuficientemente reguladas, si la medida se hubiese adoptado desde el instrumento jurídico más ajustado -por tuitivo-, a la medida de suspensión impuesta. En este caso, el estado de excepción.

D) La decisión de prorrogar el estado de alarma por un período único de seis meses

Vamos finalizando este breve repaso a otros supuestos de insuficiente regulación derivados de la pandemia por covid-19, pero no sin antes aludir a otra cuestión primordial a la hora de evaluar la aplicación que durante este tiempo se ha hecho del artículo 116 CE. Nos referimos a la prórroga de seis meses decretada sobre el actual estado de alarma vía Real Decreto 956/2020, de 3 de noviembre, decisión ampliamente criticada entre la doctrina. $Y$, es que, a pesar de que el artículo 116.2 CE no establece un plazo máximo de duración de la misma, existen argumentos más que de sobra para considerar la actual

\footnotetext{
${ }^{82} \mathrm{Y}$, es que, como apunta VERA SANTOS, J. M., "States of exception in the Spanish Constitution of 1978: Theory and practice", op. cit., apartado 3.4, en virtud de lo dispuesto en el artículo 7 LOEAES, "la normativa y el sentido común (...) requiere del establecimiento de un mando único que gestione la situación de crisis que provoca la declaración del estado de alarma, nunca diecinueve mandos" -los de las diecisiete comunidades autónomas, además de Ceuta y Melilla-. Vid. nota 49.
} 
prórroga como abiertamente contraria a la sistemática y al espíritu de la Constitución.

En este sentido, es de recibo comenzar señalando la función de control de los poderes extraordinarios que la Constitución reconoce al Congreso de los Diputados, ello cuando de aplicar el artículo 116 CE se trata. Más concretamente, y al margen del deber ejecutivo de dación de cuentas a la Cámara Baja, esta asume un rol decisivo de codecisión periódica para la prórroga del estado de alarma, función constitucional que le es irrenunciable ${ }^{83}$ ¿Cuál debe ser el plazo máximo a partir del cual ha de considerarse que no es posible el cumplimiento de tan importante labor? En ausencia de jurisprudencia constitucional al respecto, y partiendo siempre del carácter estrictamente indispensable y la proporcionalidad que han de revestir las medidas adoptadas -artículo 1.2 LOEAES-, lo razonable es pensar que la prolongación no sea superior al plazo máximo inicial de duración del estado de alarma, tal y como sucede con el estado de excepción ${ }^{84}$. De esa manera, se asegura el adecuado control al Gobierno por parte de un Congreso de los Diputados que podrá valorar con mucho más rigor la justificación o no de ciertas medidas a quince días vista, en lugar de los seis meses actuales.

En definitiva, lo adecuado desde un punto de vista constitucional habría sido proceder, como se hizo entre marzo y junio del año 2020, a la prolongación del estado de alarma cada quince días, lo cual habría evitado el actual descontrol de un estado de alarma que, con la Constitución en la mano, se encuentra nuevamente desbordado.

\footnotetext{
${ }^{83}$ ARAGÓN REYES, M., "La prórroga del estado de alarma", op. cit., añadiendo que esa renuncia supondría además arrebatar a la minoría "su derecho al ejercicio del control parlamentario, y a la opinión pública el conocimiento del debate que, sobre la prórroga, en la Cámara habrá de realizarse".

${ }^{84}$ RUIZ ROBLEDO, A., "El estado de alarma: donde quiere el gobernante", en El País, 6 de noviembre de 2020, es rotundo al afirmar la obligatoriedad de interpretar el silencio del artículo $116 \mathrm{CE}$ en un único sentido, el del establecimiento de "una prórroga corta. Sea una interpretación sistemática de la Constitución ("Monarquía parlamentaria”); sea analógica con el estado de excepción (prórroga igual al plazo original); sea basándonos en los principios generales del Derecho procesal (no hay ni una sola norma que establezca una prórroga superior al plazo original: desde los reglamentos de las Cortes hasta la Ley del Procedimiento Administrativo)". De la misma opinión, ARAGÓN REYES, "La prórroga del estado de alarma", op. cit.
} 


\section{PROPUESTAS DE LEGE FERENDA}

Una vez realizadas las oportunas reflexiones en relación con las principales deficiencias regulatorias que, tanto la crisis aérea de 2010 como la actual emergencia sanitaria han sacado a la luz, este trabajo quedaría incompleto si no incluyera, aunque sea, una breve reflexión sobre la manera en que podrían subsanarse dichas lagunas. En este sentido, se ha defendido, con buen criterio, por cierto, la modificación del artículo 4 LOEAES en el sentido de regresar a la relación ejemplificativa de los presupuestos de hecho habilitantes del estado de alarma, básicamente porque "la excepción es imprevisible por naturaleza" ${ }^{\prime 25}$. Aclarada, de paso, la operatividad del estado de alarma en supuestos de conflictividad social, se haría igualmente necesaria la reforma del artículo 11 LOEAES, para incluir una nueva relación de medidas a adoptar dependiendo de la gravedad de la emergencia surgida ${ }^{86}$. Como también sería deseable concretar qué debe entenderse por "movilización" del personal -artículo 12.2 LOEAES-, así como cuál ha de ser el papel de las Comunidades Autónomas en la aplicación del propio estado de alarma ${ }^{87}$.

Desde una perspectiva algo diferente pero no incompatible, y centrándonos ya en la actual situación de pandemia, otra parte de la doctrina ha cuestionado si, transcurridos más de nueve meses desde la declaración del primer estado de alarma en marzo, sigue estando justificado recurrir a un instituto que el artículo 1.1 LOEAES prevé solo para circunstancias extraordinarias ${ }^{88}$. En este sentido,

${ }^{85}$ GARRIDO LÓPEZ, C., "Naturaleza bifronte y funcionalidad del estado de alarma frente a emergencias naturales, crisis sanitarias y conflictos de naturaleza social", en el Seminario "Excepcionalidad y derecho: el estado de alarma a debate", organizado por la Fundación Manuel Giménez Abad, celebrado el 21 de octubre de 2020, acceso el 6 de diciembre, disponible en https://multimedia.cortesaragon.es/library/items/4724. Asimismo, GARRIDO LÓPEZ, "La naturaleza bifronte del estado de alarma y el dilema limitación-suspensión de derechos", Teoría y realidad constitucional, núm. 46, 2020, pp. 399-401. Más sobre la cuestión, CRUZ VILLALÓN, P., Estados excepcionales y suspensión de garantías, op. cit., p. 66 y ss.

${ }^{86} \mathrm{Y}$ de paso, podría clarificarse el alcance de ciertas actuaciones que, como se señala desde la propia academia, podrían revestir naturaleza suspensiva. En este sentido, REQUEJO RODRÍGUEZ, P., ¿Suspensión o supresión de los derechos fundamentales?, en Revista de Derecho Político, núm. 51, 2001, p. 115, poniendo como ejemplo de ello el hecho de que "la movilización del personal de industrias, empresas o servicios previamente intervenidos y la consiguiente imposición de prestaciones obligatorias parecen dejar en suspenso los derechos de huelga y de adopción de medidas de conflicto colectivo".

${ }^{87}$ GARRIDO LÓPEZ, C., "Naturaleza bifronte y funcionalidad del estado de alarma frente a emergencias naturales, crisis sanitarias y conflictos de naturaleza social", op. cit.

${ }^{88}$ SOSA WAGNER, F. y FUERTES, M., "Alarma: otra chapuza más", en El Mundo, 28 de octubre de 2020, quienes, de manera muy ilustrativa, afirman que "no es posible estar en continua alarma y excepción de la misma manera que no puede estar un despertador continuamente despertándonos". 
la otra opción pasaría por adaptar la legislación sanitaria ${ }^{89}$, especificándose cuáles son las facultades extraordinarias que pueden asumirse, qué autoridad puede adoptar qué medidas, así como cuáles son los instrumentos jurídicos y controles adecuados a tal efecto ${ }^{90}$, evitándose con ello la situación de caos e inseguridad jurídica vivida.

Pues bien, desde nuestro punto de vista, tanto una posición como la otra encuentran un escollo básico de cara a su eficaz aplicación en las crisis más intensas. Y, es que, no estaría de más modificar la LOEAES para ajustarla mejor a las situaciones producidas en los años 2010 y 2020, desde luego. Como también cabría reformar la legislación sanitaria vía ley orgánica, de manera que se clarificasen las reglas a seguir a la hora de restringir derechos fundamentales, incluso por unos ejecutivos autonómicos que, entonces ya sí, estarían legitimados para ello.

El problema es que, tanto en un caso como en el otro, el margen de actuación de los poderes del Estado ante situaciones de emergencia extremas continuaría siendo ciertamente limitado pues, como ya se ha recordado en varias ocasiones, resulta inconstitucional suspender de manera general derechos fundamentales si no es a través de los mecanismos establecidos en el artículo 55.1 CE. Por eso, y siendo rigurosos ${ }^{91}$, o se reforma la Constitución o la modificación de la legislación ordinaria será muy útil para aportar seguridad jurídica, en efecto, pero siempre y cuando las situaciones de emergencia no exijan la suspensión general en materia de derechos fundamentales. Llegado ese caso, solo cabría recurrir a los estados de excepción y de sitio.

\footnotetext{
${ }^{89}$ Ya se ha dicho antes que la Ley Orgánica 3/1986, de 14 de abril, de Medidas Especiales en Materia de Salud Pública, no se encuentra pensada para ser aplicada sobre grupos tan amplios de población. En esa línea, COTINO HUESO, L., "Restricciones a la libertad de circulación en la legislación ordinaria sanitaria y en el estado de alarma por la COVID-19", en el Seminario "Excepcionalidad y derecho: el estado de alarma a debate", organizado por la Fundación Manuel Giménez Abad, celebrado el 21 de octubre de 2020, acceso el 28 de noviembre, disponible en https://multimedia.cortesaragon.es/library/items/4724; y SOSA WAGNER F., y FUERTES, M., "Alarma: otra chapuza más", op. cit.

${ }^{90}$ Como señala BETANCOR, A., "Estado de pandemia, pandemia de Estado", El Mundo, 27 de julio de 2020, "Las leyes de salud públicas ni fueron pensadas para gestionar pandemias de duración temporal indeterminada (esa situación de "vigilancia epidemiológica permanente" en que consiste, según el Gobierno, la nueva normalidad); ni tampoco se preocuparon de articular controles a los que someter a la Administración. Y un poder sin control tiende, por la propia naturaleza (histórica) de las cosas, a la arbitrariedad".

${ }^{91}$ Pues es cierto que, siguiendo a FEREJOHN, J. y PASQUINO, P., "The law of the exception: a typology of emergency powers". International Journal of Constitucional Law, vol. 2, Issue 2, 2004 , p. 233, hace ya años que los Estados recurren a legislación ordinaria para afrontar situaciones de anormalidad constitucional, lo que implica "en cierto modo, un cambio permanente en el sistema constitucional de derechos y procedimientos".
} 
A partir de ahí, nuestra principal propuesta de lege ferenda pasa, no por añadir nuevos instrumentos que completen o perfeccionen a los ya existentes, sino por eliminar la figura del estado de alarma, por cuanto su regulación constituye una redundancia regulatoria que, a los hechos nos remitimos, está sirviendo además de velo jurídico bajo el cual adoptar medidas que chocan frontalmente con las reglas básicas del derecho de emergencia constitucional. A destacar sobre el resto, la imposibilidad de suspender derechos fundamentales en estado de alarma y de asegurar un adecuado control parlamentario y jurisdiccional. $Y$ ello por no hablar de la igual inobservancia de otras reglas básicas del derecho constitucional español, como son las relativas al sistema de fuentes y a la falta de competencia de los gobiernos autonómicos para restringir derechos fundamentales.

No sería descabellado, decimos, la supresión del estado de alarma, no teniendo ningún inconveniente en admitir la poca originalidad de una propuesta que, como es sabido, fue ya objeto de discusión en los debates constituyentes $^{92}$. La razón principal es la ya apuntada, el hecho de que se trata de una institución innecesaria por cuanto, utilizada adecuadamente, no aporta al Ejecutivo ningún medio adicional a los que ofrece la legislación ordinaria ${ }^{93}$, posición esta última que ya hemos tenido ocasión de secundar en otro sitio ${ }^{94}$.

Sobra el estado de alarma en la Constitución salvo, claro está, que se quiera reformar el artículo 55.1 CE para incluir la posibilidad de suspender derechos fundamentales bajo su vigencia. Pero, en ese caso, habría que proceder a la igual modificación del artículo 116 CE y de la LOEAES para, por un lado,

${ }^{92}$ Como se nos recuerda en PASCUA MATEO, F., Sinopsis artículo 116, edición digital, disponible http://www.congreso.es/consti/constitucion/indice/sinopsis/sinopsis.jsp?art=116\&tipo=2, p. 2, las reticencias respecto a la constitucionalización del estado de alarma quedaron evidenciadas a través de las enmiendas presentadas por Alianza Popular y el Grupo Comunista, en el Congreso de los Diputados, y por el Grupo Progresistas y Socialistas Independientes, en el Senado, si bien "al final se impuso la opinión de los Grupos Centrista y Socialista, favorables a la incorporación de esta figura a las situaciones de anormalidad".

${ }_{93} \mathrm{Al}$ margen de las leyes sanitarias, podría aplicarse, por ejemplo, la Ley 17/2015, de 9 de julio, del Sistema Nacional de Protección Civil; o la Ley 36/2015, de 28 de septiembre, de Seguridad Nacional. Defendiendo el carácter innecesario del estado de alarma, CARRO MARTíNEZ, A., "Artículo 116 CE: situaciones de anormalidad constitucional", en ALZAGA VILLAAMIL, Ó. (Dir.) Comentarios a la Constitución Española de 1978, Tomo IX, Edersa, Madrid, 1998, p. 253, al afirmar que, "en puridad, el estado de alarma y la nada son la misma cosa, porque las facultades de la autoridad son las mismas que le corresponden en período de normalidad".

${ }^{94}$ Vid. La defensa de la Constitución. El derecho de emergencia constitucional y el artículo 55 $C E$, op. cit., pp. 139 y ss., para descartar la inclusión del estado de alarma dentro del concepto de derecho de emergencia constitucional. 
establecer el correspondiente sistema de autorización parlamentaria previa a dicha suspensión y, por otro, diferenciarlo del estado de excepción en términos suficientes para que ambos instrumentos no se confundieran en la práctica. Como también habría que aprovechar la ocasión para concretar a nivel constitucional cuál ha de ser la duración máxima de la prórroga del estado de alarma.

De igual modo, sería lógico incorporar al Texto constitucional la posibilidad de la suspensión general del derecho a la libertad de empresa ${ }^{95}$, no pareciendo recomendable, en cambio, hacer lo propio con el derecho de sufragio -podría ser más peligroso que beneficioso-. Bastaría con introducir en la LOREG una indicación en relación con el procedimiento a seguir para cancelar unas elecciones ya convocadas, aprovechando la experiencia de lo sucedido con los comicios autonómicos gallegos y vascos durante este año.

Pero, por encima de todo, y para concluir, lo que de verdad urge es acabar con el actual estado de estigmatización existente en torno al artículo 116 CE, como si su aplicación supusiera una amenaza para la supervivencia del orden constitucional, cuando es precisamente lo contrario. Al lógico control jurisdiccional de las decisiones y actos realizados por los poderes públicos se le une, con dicha activación, una fiscalización parlamentaria que se hace especialmente palpable en el momento en el que el Congreso de los Diputados ha de autorizar al Gobierno la declaración y/o prórroga de los estados excepcionales. El problema es que, si ya el estado de alarma se encuentra revestido de un halo de negatividad notorio, qué decir del estado de excepción, ignorado en su aplicación incluso cuando la entidad suspensiva de las restricciones en materia de derechos fundamentales era más evidente. Hace falta tanta pedagogía como responsabilidad por parte de las principales fuerzas políticas a la hora de utilizar oportunamente los instrumentos excepcionales dados por el constituyente. Pero, llegados a este punto, lo que más echamos en falta es la actuación de un Tribunal Constitucional cuya jurisprudencia marcará el devenir de unos estados excepcionales que, dado lo convulso de los tiempos que vivimos, no hay que descartar deban ser nuevamente empleados. Es el Estado de derecho lo que está en juego.

${ }^{95}$ Como ya se ha indicado antes, nos referimos a las suspensiones producidas de manera desvinculada a los confinamientos generales casi totales o a los toques de queda. Esto es, al cierre general casi total de los comercios, ello en paralelo o contraposición a la posibilidad de circular por las vías de uso público. 